\title{
ON THE PROBLEM OF CORPORATE STRATEGIES OF DEVELOPMENT FOR HUMAN RESOURCES
}

\author{
LILIA MYKHAILYSHYN, OLGA LELIUK, YURII KOROVCHYK
}

\begin{abstract}
The article defines the theoretical aspects of the formation of corporate development strategies of human resources and the research features of the development system of human resources at the Academy DTEK. Conceptual approach to providing continuous professional development of human resources of the enterprise is offered.
\end{abstract}

Keywords: human resources, staff development, role model, employee development programs, school of managers, internships, graduation projects.

\section{INTRODUCTION}

Considering realities of modern development of social and economic systems it is proved that problems of management of human resources become more and more important, as human resources are the central component and driving force of any of them. One of the most important components of a control system of human resources is development of human resources. The organizations of any forms of ownership and fields of activity in this sphere act up considerably both on functional and tactical levels, as well as on the strategic level of their functioning.

\section{ANALYSIS AND DisCUSSION}

The founder of the theory of systems L. von Bertalanfi wrote that a system is a set of elements which interact with each other and with the environment, and this is considered a standard definition of a system as a notion.

Classifications of systems can be carried out on various bases, however the main one is grouping into three subsystems: technical, biological and social and economic.

The technical subsystem includes machinery, equipment, computers and other products which have instructions for a user. A number of decisions and resolutions in a technical system is, as a rule, limited, and consequences of decisions are usually predetermined.

The biological subsystem comprises flora and fauna of the planet, including rather closed biological subsystems. This subsystem has a large number of aspects of appliance, than technical. A number of decisions in a biological system is also limited because of slow evolutionary development of fauna and flora. However consequences of decisions in biological subsystems often are unpredictable. 
The social and economic subsystem is characterized by presence of a human in integrity of interconnected elements. It is possible to illustrate the given system by any organization and its staff. These subsystems are significantly more advanced in functioning and variety than biological ones. All the decisions in a social and economic subsystem are characterized by great dynamism in their quantity and means, as well as implementation methods. It is explained by the high rate of changes in consciousness of the person and by different nuances of his reactions to identical or similar situations [2].

Thus, the driving force of development of any social and economic subsystem is a person, who is characterized by a certain set of qualities, knowledge, skills, experience and so forth.

In the modern world almost all types of activity in any community are carried out by people who work with each other. Most of them either are hired workers or work independently or in small enterprises, getting their income depending on a personal contribution to general activity. [5, p. 5]

Taking this into account, quality of human resources comes to the forefront in any organization which employs people. Consequently, development of human resources is an instrument of achievement of a necessary quality of human resources in the organization.

If the organization pays special attention to training, vocational training and development of human resources in all the spheres of its activity, it always results in a noticeable advantage. If employees are used to studying, developing, sharing knowledge and if "the culture of training" is created in the organization, it provides a more beneficial position for the organization as it allows to quickly react on changes of the environment. For example, an enterprise can release a new product or react to change of consumer demands quicker than its competitors and that will allow it to gain competitive advantage or to satisfy a given demand of the market.

For a certain type of people professional training and development at work make up a very important condition, as the "all-life job" situation occurs less and less often these days. In present conditions employment becomes less stable and that leads to more frequent change of the place of work and therefore people change a type of activity they do to earn the living much more often during their working years [4, p. 91].

Even if a person continues to work for one organization for a long period it still means training as the organization develops as technologies develop or the person receives new spheres of responsibility. Additionally it should be noted that organizations become "flatter" on the structure therefore more various skills and abilities are necessary for workers to perform complex tasks [4, p. 92].

Consequently, insufficient attention of the organization management to development of human resources leads to the following consequences:

- losses of profit of the organization;

- inability to react to changes of the external environment;

- restrictions in duties delegation to one another;

- discontent of workers caused by desire to learn new;

- lack of knowledge for performance of new tasks;

- high turnover of staff.

Many scientists support opinion that the most effective means for overcoming negative phenomena connected with development of human resources in organizations is to use of the theory of "the selftraining organization". The founder of this theory is an American scientist, a director of the Center of organizational training at the school of management of MIT Sloan Peter Senge.

Peter Senge defines the term "self-training organization" as an organization where people constantly expand their opportunities to achieve results which they really want to reach, where they develop newer and better ways of thinking, where the collective aspiration is free and where people learn to see the general perspective all the time.

According to the scientist, increase of uncertainty in the sphere of business, economic and political shocks, growing interdependence of the world markets and world corporations became a push to radical changes: society grows to understand that current tendencies of consumption growth and environmental pollution together with growing disintegration and uncontrollability pose an 
unprecedented threat for the future in general. Today many managers recognize the necessity to learn more, because the approach to studying provided by traditional authoritative and hierarchical organizations can suffice no longer [9, p. 10].

P. Senge's concept is based on five "abilities of the organization".

The first "ability" is a skill of personal improvement. Despite the fact that a lot of energetic and vigorous people join businesses, very few of them remain "at their best" for a long time. Majority of them start to save their energy and when they are around 30-40 they start losing their devotion, feeling of the personal importance and inspiration. However only few organizations encourage their employees to move forward, as a result other organizations are stuck with unused potential of their labour resources.

The second "ability" is intellectual models. Models as stereotypes concerning various administrative situations are already predetermined for us, as well as purely household models. This is the reason why there are a lot of positive administrative ideas that remain unrealized.

The third "ability" is a general vision. Many managers and executives do not give enough significance to the fact that their personal vision of development of the organization is not clear and is not shared by all employees. According to P. Senge, it is because of a general vision that people study because they really want to, not because they are ordered.

The fourth "ability" is group training. However this case is not only about trainings or seminars, but also about free exchange of views in groups - a kind of a dialogue. P. Senge considers that dialogue between employees leads to such discoveries which are absolutely inaccessible for everyone of them separately.

The fifth "ability" is systematic thinking. All other abilities remain separate methods, a fashionable novelty of management science without this discipline. At the same time it is vital that all five "abilities" are developed not separately but as a system [6].

Usage of all the given above components in a complex leads to the creation of a developed organization which is capable of self-studing. Such organizations are better than their competitors "evolutionary".

In 1991 an American psychologist Mike Pedler singled out signs of "the self-training organization":

1. Improvement of personal skills, as far as it is a prime necessity to develop personal abilities and knowledge for development of the organization.

2. Flexibility in elaboration of a strategy. A strategy is not viewed as something invariable, set once and for all and a task to perform, but as a constantly changing matter that responds to changes and circumstances which arise.

3. Employees participate actively in a process of development of strategies and tactics of an organization, that means that ideas, values and purposes are introduced not only by top management, but also by all personnel.

4. Free access to information. An organization is open to receive information from the outside and it easily provides information on itself. Both external and internal information is used to make decisions.

5. Control and accountability contribute to the development of the organization. Systems of accounting and control are built on this principle and they have a training function.

6. Flexible system of perks. The concept of "reward" is understood more widely, than "payment". At the same time reward depends on a worker's contribution to general results; forms of possible rewards are agreed and accepted by staff and their experience.

7. The structure of the organization opens opportunities. A working place is not something constant, they are viewed as conditions, options for development and growth which can be changed rather easily. Departments, regulations and procedures can be changed.

8. An atmosphere promotes training and studying. Corporate culture at its heart encourages workers to continue professional growth and development, at the same time it recognizes their right to make mistakes and provides them with enough time to study.

9. Opportunities for self-development of employees. Training is the most important part of a career of a worker, it is planned and supported [10]. 
As any of subsystems, "the self-training organizations" can be classified. The classification of "the self-training organizations" was developed by American scientists Michael McGill and John Slokum. Its adapted version is given in Table 1.

\begin{tabular}{|c|c|c|c|c|}
\hline \multirow[b]{2}{*}{ Activity aspect } & \multicolumn{4}{|c|}{ Type of an organization } \\
\hline & $\begin{array}{c}\text { Organization that } \\
\text { knows }\end{array}$ & $\begin{array}{c}\begin{array}{c}\text { Organization that } \\
\text { understands }\end{array} \\
\end{array}$ & $\begin{array}{c}\text { Organization that } \\
\text { thinks }\end{array}$ & $\begin{array}{c}\text { Organization that } \\
\text { studies }\end{array}$ \\
\hline $\begin{array}{l}\text { Philosophy and } \\
\text { ideology }\end{array}$ & $\begin{array}{l}\text { "Best way" } \\
\text { approach. } \\
\text { Predictability and } \\
\text { control. }\end{array}$ & $\begin{array}{l}\text { Importance of } \\
\text { significant cultural } \\
\text { values. Belief in } \\
\text { main myths. }\end{array}$ & $\begin{array}{l}\text { Business is a series of } \\
\text { situations and } \\
\text { problems. } \\
\text { "Inaccuracies" are } \\
\text { dismissed. }\end{array}$ & $\begin{array}{l}\text { Study and development } \\
\text { of any relevant } \\
\text { experience, including } \\
\text { methods of its gaining. }\end{array}$ \\
\hline $\begin{array}{l}\text { Practice of } \\
\text { management }\end{array}$ & $\begin{array}{l}\text { Control according } \\
\text { to manuals and } \\
\text { instructions }\end{array}$ & $\begin{array}{l}\text { Explanation, noting, } \\
\text { strengthening of the } \\
\text { organizational } \\
\text { culture }\end{array}$ & $\begin{array}{l}\text { Identifying of the } \\
\text { problem, gathering data } \\
\text { for its solution }\end{array}$ & $\begin{array}{l}\text { Experiment, innovations } \\
\text { and initiatives } \\
\text { encouragement } \\
\text { ("constructive } \\
\text { objection"), examples, } \\
\text { failure acknowledgement }\end{array}$ \\
\hline Colleagues & $\begin{array}{l}\text { Sticking to the rules } \\
\text { without } \\
\text { questioning them }\end{array}$ & $\begin{array}{l}\text { Use culture and } \\
\text { organization values } \\
\text { as a behaviour } \\
\text { model }\end{array}$ & $\begin{array}{l}\text { Study and use standard } \\
\text { solutions that appeared } \\
\text { in the process of } \\
\text { successful problem } \\
\text { solving }\end{array}$ & $\begin{array}{l}\text { Gather and use } \\
\text { information, support } \\
\text { "constructive skepticism" }\end{array}$ \\
\hline Clients & $\begin{array}{l}\text { Should trust the } \\
\text { company }\end{array}$ & $\begin{array}{l}\text { Should believe that } \\
\text { company's values } \\
\text { guarantee positive } \\
\text { experience }\end{array}$ & $\begin{array}{l}\text { Think that every } \\
\text { problem can be solved }\end{array}$ & $\begin{array}{l}\text { Are learners together } \\
\text { with employees; a part of } \\
\text { an open and never- } \\
\text { ending dialogue }\end{array}$ \\
\hline Changes & $\begin{array}{l}\text { Gradual; settings } \\
\text { for the "best way" } \\
\text { realization }\end{array}$ & $\begin{array}{l}\text { Within the } \\
\text { framework of main } \\
\text { myths, values of the } \\
\text { organizational } \\
\text { culture }\end{array}$ & $\begin{array}{l}\text { Programmes, problems } \\
\text { solving, the best way to } \\
\text { fight failures }\end{array}$ & $\begin{array}{l}\text { A part of a never-ending } \\
\text { process "experience- } \\
\text { analyses-assumption- } \\
\text { experiment-experience" }\end{array}$ \\
\hline
\end{tabular}

Tab. 1. Classification of self-studying organizations after M. McGill and J. Slokum [7].

The knowing organizations are the oldest type. They are successful in the conditions of stability of the market, and they do not particularly need to study and train. To be more precise, training takes place only when required and has an adaptive character.

The organizations which understand and think, can be placed among transitional types of organizations, the latter ones being "self-training" by their nature.

This conception helps to change the relations and induces people to recognize importance of training. It helps people to understand that they need to control training themselves, but not to perceive it as something others impose on them, when they are sent to study.

It must be said that specialists did not come to a common decision on whether it is possible to perceive organizations, which have learning capability, as self-training organizations. However this concept itself is useful as it helps to understand the matter of training which is carried out in an organizational context, and also factors promoting and interfering initiatives of managers which encourage and implement training activities in the organization [4, p. 101].

It is important to emphasize that the concept of the self-training organization is considered as a template or model which the operating organizations can copy, but which cannot be fully reached.

It is possible to distinguish certain organizations which have certain features of "the self-training organizations" among domestic organizations. One of them is the largest private vertically integrated energy company of Ukraine DTEK, within which the corporate university - DTEK Academy successfully functions. 
The management of DTEK considers qualified specialists and managers the key factor providing their competitive advantage therefore training of this category of personnel is the most important instrument of development of the company. The academy is a centralized control center over the system of knowledge in all enterprises of the company. Corporate university includes educational programs which cover all important spheres of administrative activity work and are aimed at teaching employees to approach and solve professional tasks systematically, and give them knowledge and skills necessary in daily working activity. The conception of DTEK Academy is based on the "role model" which comprises development of four IQs: IQ (formal and logical), EQ (emotional), LQ (training and studying) and SQ (social). All staff of the corporate center and ITR of personnel of the DTEK enterprises can benefit from implementation of programs for development of competences ("Energy of Knowledge", "Energy of the leader") which are focused on improvement of knowledge, skills necessary for work in a modern business organization.

"Energy of Knowledge" is a program intended for the employees selected in a talent pool. Training is focused on increase in personal efficiency in human resources management and business processes management, on revelation of EQ (emotional intelligence) capacity. Top management of the company acts as teachers, famous domestic business coaches and invited speakers of the international business schools also participate in the program. The Energy of the Leader program is intended for the managers of DTEK participating in the TOP-50 program (selection and training of successors on senior positions). The program is aimed at development of abilities, which allow implementing innovative crossfunctional projects with a large number of various resources. Classes for participants of the program are conducted by heads of DTEK and professors of the international business schools. All programs and projects which were implemented and are implemented from the moment of creation of DTEK Academy are presented in Fig. 1.

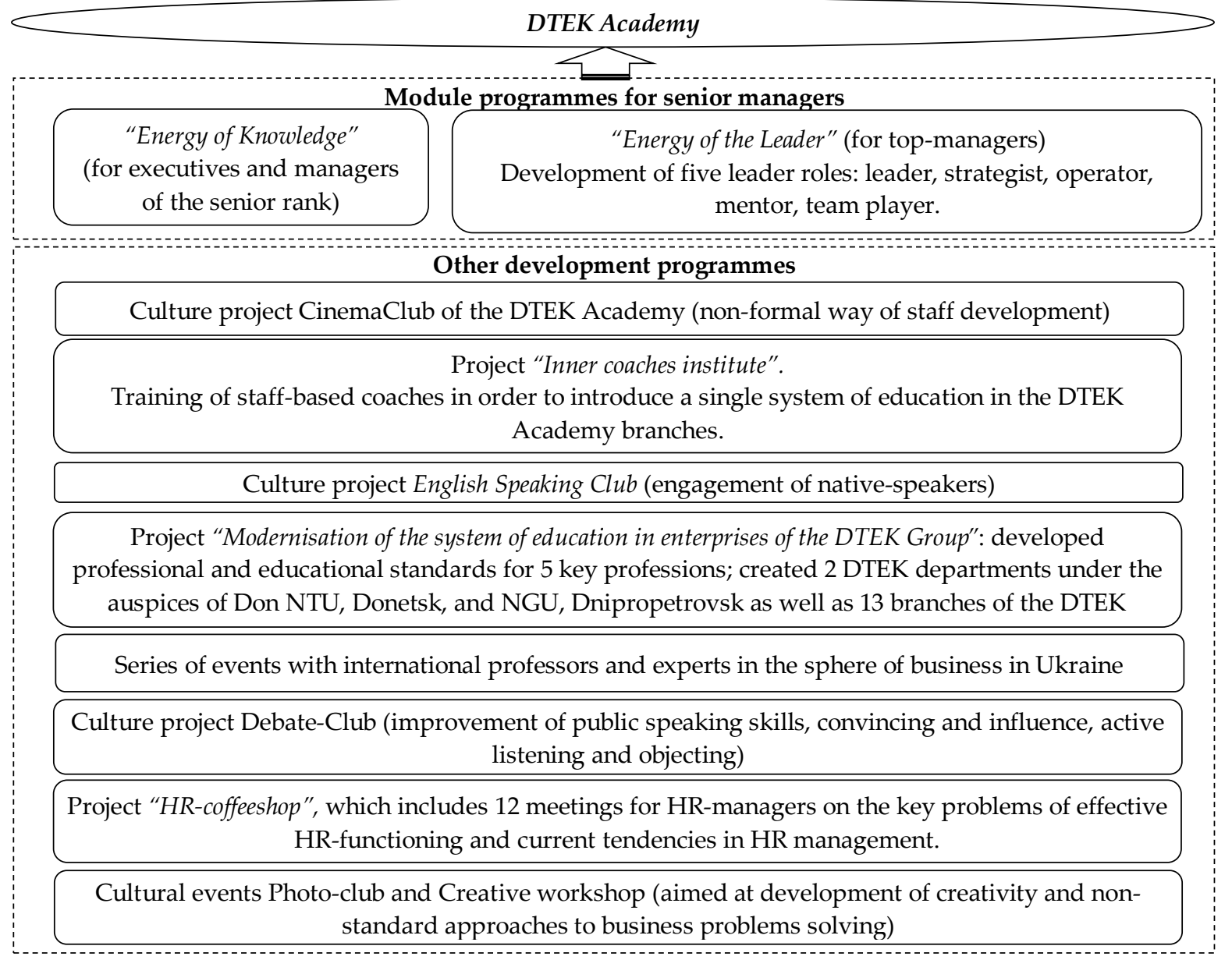

Fig. 1. Programmes of staff development, put into practice by the DTEK Academy since 2010 [1]. 
The management of DTEK strives to achieve those level and quality of education which can be received and compared to training in the MVA program in the best business schools. [8]

Another enterprise, which pays much attention to development of the human resources the Metallurgical Complex Branch of CJSC "Donetskstal" steel works. The system of development in this enterprise is carried out according to conceptual approach to ensure continuous professional development of human resources of the enterprise (Fig. 2).

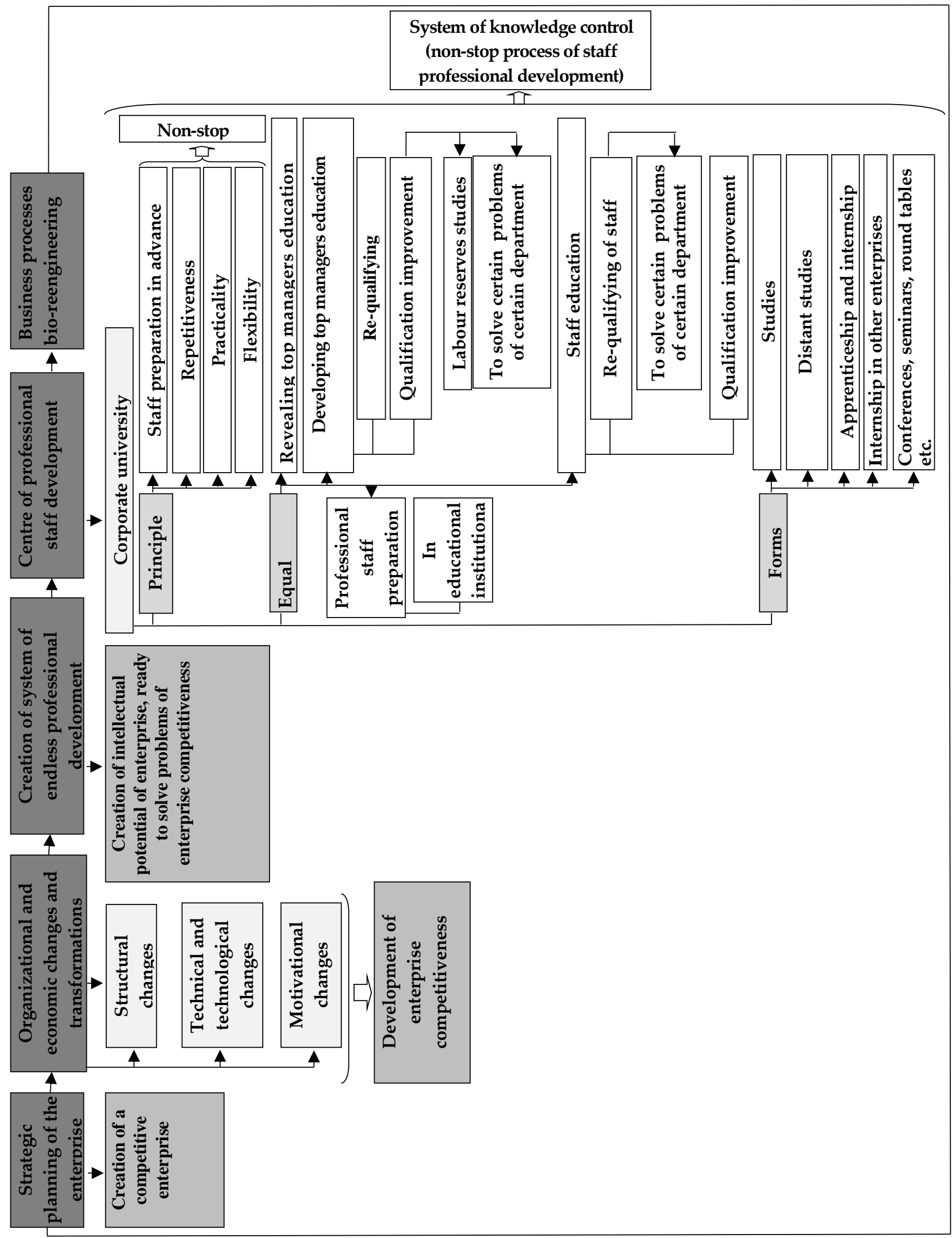

Fig. 2. Conceptual approach to providing continuous professional development of human resources of the enterprise [3, p. 287] 
Within this approach there was created the School of managers the purpose of which is preparation and professional development of the workers who are a part of a talent pool on senior positions.

Components of process of training at School of managers are stated in Fig. 3.

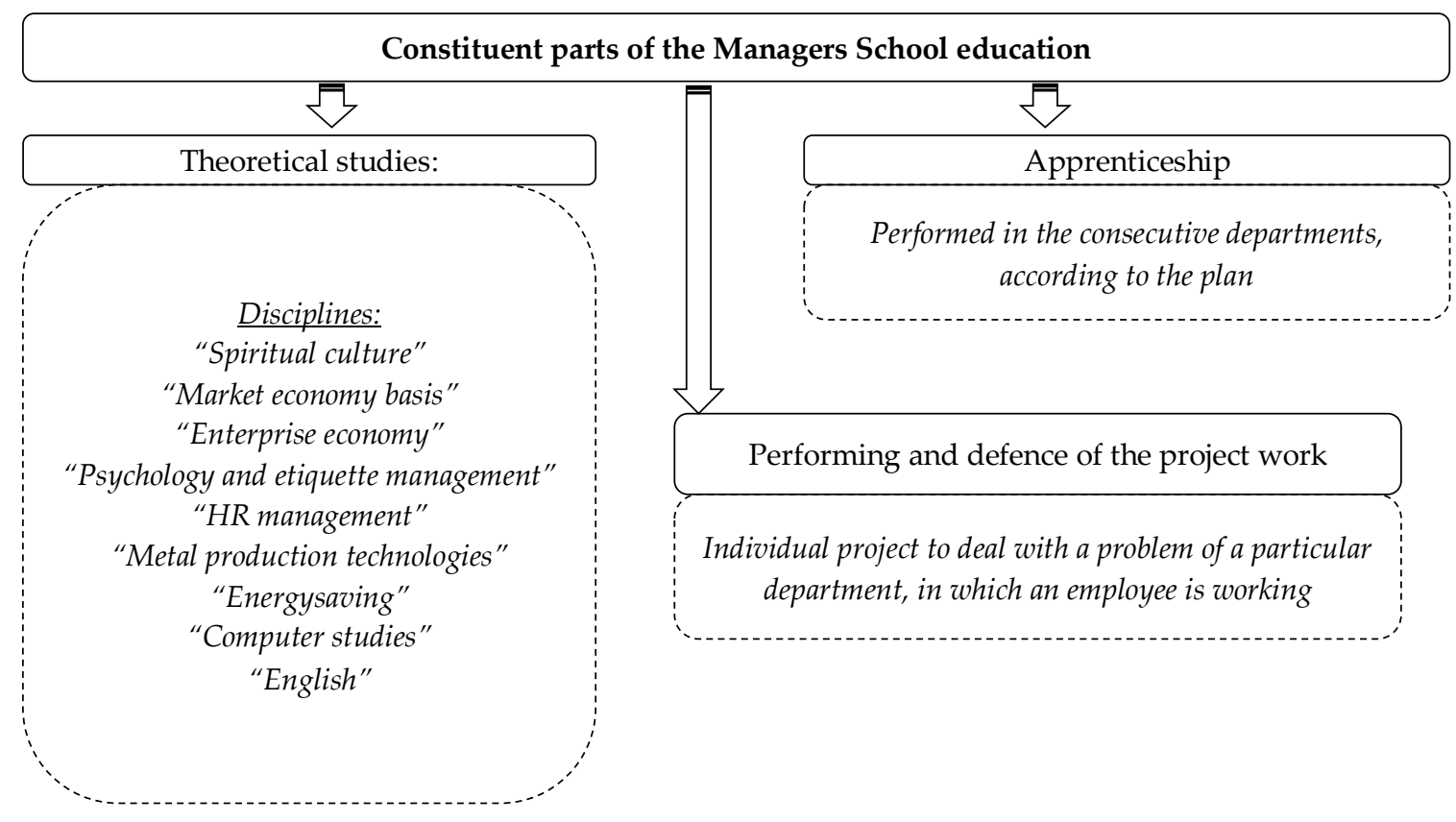

Fig. 3. Components of the studying process at the School of Managers.

The school of managers gives theoretical knowledge on various subject matters, such as disciplines of economic orientation (fundamentals of market economy, economy of the enterprise), disciplines on psychological aspects of administrative activity (management of human resources, psychology and ethics of management) and also special technological disciplines on the example of their own production technologies (technology of metallurgical production, energy saving, the mechanical equipment of the enterprises of ferrous metallurgy) and various aspects corporate of cultures of the enterprise (bases of spiritual culture).

Knowledge gained at the School of managers allows not only to broadening horizons of reservists, removing them out of limits of the structural division, to understanding logic and schemes technological and business processes of the enterprise, but also gives separate tools and skills for effective administrative activity: ways of the solution to conflict situations in collective, psychological aspects of motivation of personnel, project management, holding production meetings, conducting business negotiations and so forth.

\section{CONCLUSIONS}

The following conclusions can be drawn on the basis of the above given information:

1. Human resources are the mobile force of functioning of social and economic systems.

2. Special attention of the organizations to training, vocational training and development of human resources always provides noticeable advantages of an organization over its competitors.

3. One of the most effective means to provide organizations with qualitative labor forces is to use the main ideas of the concept "self-training organization" that will allow preventing emergence of the negative phenomena caused by development of human resources in the organizations.

4. Among the striking examples of domestic enterprises, which put programs of development of human resources into practice one can find the DTEK company and Metallurgical Complex Branch of CJSC Donetskstal steel works. The increase in the level of professional and personal skills of employees 
of these organizations allows them to beat their competitors in the long run, if changes in functioning of social and economic systems are taken into account.

\section{REFERENCES}

[1] DTEK academy. Available at: https://en.wikipedia.org/wiki/DTEK_Academy

[2] Crisis management by the enterprise (2005). Available at: http://library.if.ua/book/60/4207.html (in Ukrainian)

[3] Kalinina S.P., Kovalevska V.V., Lanska S.P. Formation of Quality of Labor in a Control System of Human Resources. MONMS Ukrainy, Donets. Nats. Un-t, Donetsk, 2010. (in Ukrainian)

[4] Book 1: Introduction to management. In: Golubkin V.N. (Ed.) Management in Operation. MIM LINK, Zhukovsky, 2013. (in Russian)

[5] Book 2: Management of people and organizations. In: Golubkin V.N. (Ed.) Management in Operation. MIM LINK, Zhukovsky, 2013. (in Russian)

[6] The studying organization. Management of Knowledge. Available at: https://sites.google.com/site/upravlenieznaniami/obucausaasa-organizacia (in Russian)

[7] Orchakov O.A. Theory of the Organization. Tsentr distantsionnykh obrazovatelnykh tekhnologiy MIEMP, Moscow, 2010. Available at: https://online.muiv.ru/media/lib/books/teoriyaorganizatsii/xbook031/book/index/index.html (in Russian)

[8] Official site of the DTEK company. Available at: https://dtek.com/en/

[9] Peter Senge. The Fifth Discipline. The Art and Practice of the Learning Organization. Kharkov, 2006. Available at: https://www.e-reading.club/bookreader.php/112324/Pyataya_disciplina.pdf (in Russian)

[10] Short course of lecture of the discipline "Management". Available at: https://studme.com.ua/105405036519/menedzhment/obuchenie_organizatsii.htm (in Ukrainian)

Address: Lilia Mykhailyshyn, Yurii Korovchyk, Vasyl Stefanyk Precarpathian National University, 57, Shevchenko Str., Ivano-Frankivsk, 76018, Ukraine;

Olga Leliuk, Vasyl' Stus Donetsk National University, 21, 600 ${ }^{\text {th }}$ Anniversary Str., Vinnytsia, 21021, Ukraine.

E-mail: Lilya-M@ukr.net, yuriha@ukr.net, leliuk.olga@gmail.com

Received: 25.08.2018; revised: 14.11.2018.

Михайлишин Лілія, Делюк Ольга, Коровчук Юрій. До питання про корпоративні стратегії розвитку людських ресурсів. Журнал Прикарпатського університету імені Василя Стефаника, 5 (3-4) (2018), 70-77.

У статті визначено теоретичні аспекти формування корпоративних стратегій розвитку людських ресурсів, досліджено особливості формування системи розвитку людських ресурсів в Академії ДТЕК. Запропоновано концептуадьний підхід до забезпечення безперервного професійного розвитку людських ресурсів підприємства.

Ключові слова: людські ресурси, розвиток персоналу, рольова модель, програми розвитку співробітників, школа менеджерів, стажування, випускні проекти. 